\title{
CHINA'S HIGHER EDUCATION DEVELOPMENT: POLICY REVIEW AND RECOMMENDATIONS
}

\author{
Mai Ngoc Anh, ${ }^{1}$ Do Thi Hai Ha, ${ }^{2}$ Nguyen Dang Nui, ${ }^{3}$ \\ Khieu Thi Nhan, ${ }^{4}$ Nguyen Dinh Hung, ${ }^{5}$ Vu Tri Tuan ${ }^{6}$
}

DOI: $10.35782 / J C P P .2019 .3 .06$

\begin{abstract}
Not only playing a role in creating and spreading knowledge, bigher education institutions can also make a positive contribution to a nation's economic development and its social welfare improvement. The Chinese government has made some adjustments to its state management policy toward higher education; subsequently, massification of higher education was achieved, and several top world ranking and world-renowned universities were built as a result of projects 985 and 211. This study focuses on analyzing China's higher education system, law/legal system, and by-law documents on improving higher education; from that, the research can identify the core problems in the development of higher education system in China as well as the content needed to be solved in the coming years.
\end{abstract}

Key words: tuition fee, staffing, University council, University governance

\section{Introduction}

Higher education institutions are responsible not only for the the transmission and production of knowledge, but also make a positive contribution to the economic development as well as welfare of mankind (Thorens, 2006). Since 1978, Chinese government has implemented economic reforms towards outside the world, 'the focus of China was shifted to economic introduction to higher education in China development (Zhu and Lou, 2011 , p. 2). Lots of higher education policies had been promulgated, resulting in an unprecedented opportunities for higher education in this country. Massification has been done, world-class universities and world-renowned universities have been

1 Assoc.Prof. Ph.D., National Economics University, Hanoi, Vietnam; Email: maingocanh@ neu.edu.vn

2 Assoc. Prof. Ph.D., National Economics University, Hanoi, Vietnam; Email: hadh@neu.edu.vn

3 PhD., National Economics University, Hanoi, Vietnam; Email: nuind@neu.edu.vn

${ }^{4}$ PhD., Ministry of Education and Training, Hanoi, Vietnam; Email: ktnhan@moet.edu.vn

${ }^{5}$ MA., National Economics University, Hanoi, Vietnam; Email: hungnd@neu.edu.vn

${ }^{6}$ MA., National Economics University, Hanoi, Vietnam; Email: tuanvt@neu.edu.vn 
established. Chinese higher education system as well policies for higher education development would be reviewed; essential policies for the development of higher education institutions in China would be discussed. This research compared the current policies of tuition fees, block grant budget, and university council in China, with university governance patterns in countries shaped by the Napoleonic model or the Humboldtian model. Several suggestions for Chinese government to revise policies for higher education development in the coming years will also be discussed.

\section{Literature review and research framework}

Higher education system includes public and private institutions around the world except for UK and Ireland (Mora, 2001), and the State manage higher education development through the state control model or the state supervising model (Vught, 1989). At the time of the founding of the People's Republic of China, 'all private and missionary universities and colleges were turn into public ones' (Liu, 2016, p. 50), and over-specialized institutions were dominant throughout the higher education system due to an attempt to duplicate the Soviet model of higher education because it worked well with the planned economy (Zha, 2009). All Chinese universities were owned and directly administered by the Ministry of Education and other ministries. Higher education had, therefore, developed in accordance with the planning and administration of the Chinese government (Zhu and Lou, 2011).

With the establishment of China's economic reform and Open-Door Policy since 1978, higher education opened out 'towards the future and towards modernization' (Deng, 1993, p. 35) as well as 'better serve the socialist construction' (Deng, 1994, p 103). China's higher education entered an era of rapid development and comprehensive reform: Both central and local government participated in governing higher education system (Mok, 1999), private universities were reintroduced at the early of the 1980s (Morgan and Wu, 2011), comprehensive public universities were encouraged to launch through merger (Wang and Liu, 2009), the objective of massification of higher education had been established (Chen 2004), the world-class university and world-renowned universities had been targeted via the introduction of project 985 and project 211 (Wang et al., 2011).

To enhance the development of higher education in China, a series of policies for higher education development had been promulgated by Deng Xiaoping and his successors. The 1985, Decision on the Reform of Educational Structure issued by the Central Committee of the Communist Party of China started a process of decentralization. Decision makingpower from the central government had been initially transferred to local government and public higher education institutions. The roles and responsibilities of central and local government in higher education development had been clarified to meet the current requirements of socio-economic development at that time (Liu, 2016); university were allowed to charge tuition fees on a small number of student in public universities (Hong, 2018); the role and responsibility of the president as well as Communist Party Committees in public universities had been re-determined (Liu, 2017). The Guidelines for Educational Reform and Development in China was promulgated in 1993, provided more funding channels for public universities, ranging from non-state budget through school-run industry, social donations, financial contribution from students and fundraising (Mok, 2002; Chen, 2004). The Guideline reaffirmed the 1985 Decision as 'The central government would refrain 
from direct control over education. Instead, government acted as a facilator' ( $\mathrm{Li}$ and Yang, 2014, p. 13). The Higher Education Law, launched in 1998 has institutionalized the previous policies on university governance in the context of university autonomy, and the law was revised in 2015 (Wang, 2010; Chinese National Progress, 2016). In 2015, the Overall Plan for Comprehensively Promoting the Construction of the world's first class Universities and first class Disciplines was enacted by the State Council. The Double first-class Plan was clearly put forward to promote a number of universities and disciplines to enter into the world's leading ranking, to accelerate the modernization of higher education governance system and governance ability (Higher education evaluation center of the ministry of Education, 2016)

Although policies for Chines higher education development including the Law on Higher Education, Law on the Promotion Of Non-public Schools of the People's Republic of China, by-law documents for the development of the higher education system have been discussed among Chinese and international scholars (Huang, 2003; Chen, 2004; Wang et al., 2011; Mohrman et al. 2011; Su et al., 2015; Liu, 2017; Jia and Ericson, 2017), and the limitations and implication policies for university governance have been pointed out. The research on policies on Chinese higher education development would still remain relevant, particularly in comparison to other countries shaped by the Napoleonic model or the Humboldtian model.

\section{Overview of Higher Education System in China}

There are more than 2560 higher education institutions in China, of which 118 are public universities, including 71 universities affiliated with the Ministry of Education, 50 higher education institutions affiliated with other ministries or central government's branches; the remains - approximately 1709 public higher education institutions and 733 private institutions - are managed by local governments (Xiulan, 2011). The number of regular HEIs offering undergraduate education and above are 1219, the number of regular tertiary vocational colleges are 1341 . Before 2008, the non-government HEIs used to be dominated by the tertiary vocational college education, but now private universities and tertiary vocational colleges develop simultaneously in China. In addition, 600 universities affiliated with local and provincial government are being transformed into vocational education with a strong orientation on employability (Serger et al., 2015).

Table 1: Changes in number of higher education institutions in China in the period of $2005-2015$

\begin{tabular}{|l|r|r|r|}
\hline & $\mathbf{2 0 0 5}$ & $\mathbf{2 0 1 0}$ & $\mathbf{2 0 1 5}$ \\
\hline Number of universities & 701 & 1112 & 1219 \\
\hline $\begin{array}{l}\text { In which: number of non-government regular HEIs offering } \\
\text { undergraduate education and above }\end{array}$ & 27 & 371 & 423 \\
\hline Number of tertiary vocational colleges & 1091 & 1246 & 1341 \\
\hline $\begin{array}{l}\text { Proportion occupied by the number of students enrolled by regular } \\
\text { HEIs }\end{array}$ & 59.8 & 66.3 & 68.6 \\
\hline Proportion occupied by the number of students enrolled by colleges & 29.9 & 23.2 & 17.9 \\
\hline
\end{tabular}

Source: HEEC, 2016 
While the number of regular HEIs has increased rapidly since the beginning of the era of economic reform, a small number of elite universities had been selected to become 'world-class' universities. So far, 112 and 39 public universities have been selected and supported by Project 211 and 985 respectively. No new universities have been added to the list since 2011. The original objective of 211 project aimed to improve the capabilities and competitiveness of some 100 universities in education, research, management and outcome impact. As consequence, Project 211 universities account for four-fifths of doctoral students, two-thirds of graduate students, and one-thirds of undergraduates in China (Serger et al., 2015). Project 985 targeted a small group of elite universities with the aim of turning them into world class universities. Thanks to the huge investment from public funds for a small fraction of the universities, 2 universities were ranked in the top 50,10 universities ranked in the top 200, 19 universities ranked in the top 300 and 44 in the top 500 universities all over the world (Reddy et al., 2016).

Additionally, more than 43 million students were enrolled in HEIs in 2015, of which, the number of undergraduates annually enrolled by regular HEIs was 5,66 million, the number of students enrolled by colleges was 6,12 million and the number of HEI graduates was 5,20 million in 2015. According to the report of Higher education evaluation center of the ministry of Education (2016), at the undergraduate level, majors related to science, engineering, agriculture and medicine account for about $50 \%$, the literature, history and philosophy related majors account for $20 \%$, and the economics, business, law and education related majors account for $30 \%$ of the total enrollment undergraduate in China. At the graduate level, the proportion of different disciplines was 50\%, 20\%, 30\% respectively in 2015 .

\section{Table 2: Changes in the number of undergraduate students enrolled by the regular HEIs according to the disciplines in $2005-2015$}

\begin{tabular}{|l|r|r|r|}
\hline \multicolumn{2}{l}{} & Unit: 10000 persons \\
\hline Total & $\mathbf{2 0 0 5}$ & $\mathbf{2 0 1 0}$ & $\mathbf{2 0 1 5}$ \\
\hline Subtotal of literature, history and philosophy & 258.6 & 387.2 & 423.7 \\
\hline $\begin{array}{l}\text { Subtotal of students majoring in Economics, Management, Law and } \\
\text { Education }\end{array}$ & 41.5 & 68.8 & 76.3 \\
\hline $\begin{array}{l}\text { Subtotal of students majoring in Science, Engineering, Agriculture } \\
\text { and Medicine }\end{array}$ & 120.1 & 108.9 & 121.5 \\
\hline Subtotal of students majoring in Teaching training & 25.8 & 35.9 & 191.6 \\
\hline
\end{tabular}

Source: HEEC, 2016

In HEIs, the average total credits are 164, but it differentiates among 985 project HEIs, 211 project HEIs, regular HEIs, independent colleges. The total credits cover both compulsory and selective courses, with the average proportion is $79,54 \%$, and $20,46 \%$ respectively. Public compulsory courses, particularly political courses such as Marxism and Maoism are strictly controlled by the state because 'The task of China's higher education is to cultivate high-level specialized personnel with social responsibility, innovative spirit and practical ability, develop scientific and technological culture and promote the construction of socialist modernization' (HEEC, 2016, p7) 


\section{Laws and By-law documents for Higher Education Development in China}

First, about the establishment and development of higher education system: Law on Higher Education of China defines the roles, responsibilities of central government and local government in their relationships with higher education institutions: "The state formulates higher education development planning, establishes institutions of higher learning and adopts various forms to actively develop the cause of higher education in accordance with the requirements of economic construction and social development'. (Article 6); 'Establishment of institutions of higher learning shall be subject to the examination and approval of the department of education administration under the State Council, among the establishment of institutions of higher learning imparting specialty education may be subject to the examination and approval of the people's governments of the provinces, autonomous region' (Article 29); 'Specific standards for the establishment of institutions of higher learning shall be formulated by the State Council, Specific standards for the establishment of other institutions of higher education shall be formulated by the departments concerned authorized by the State Council or people's governments of the provinces, autonomous regions and municipalities directly under the Central Government in accordance with the principles prescribed by the State Council'. (Article 25). Based on the China's higher education law, Beijing Municipal Commission (2017) enacted Regulations on the Establishment of Nonpublic Higher Education Institutions of Beijing; Shanghai Municipal Commission (2017) issued Regulations on the Establishment of Non-public Higher Education Institutions of Shanghai. Both of these by-law documents emphasized on the minimum requirements of staffing, land and facilities for the establishment of newly built higher education institutions.

Secondly, Regarding the university governance at institutional level, the China's higher education law asserts that "The president of the institution of higher learning shall be the legal representative of the institution of higher learning. (Article 30). According to the law, university president takes overal responsibility for the university's operation under the leadership of the university's Communist Party Committee, also known as the governing board. By-law documents state that the presidents of the university affiliated with the ministries are appointed by the ministers, the municipal government appoints the presidents of university affiliated with them, including minban and independent colleges (Hong, 2018). Although university council has been suggested to establish in some public universities; they work as a consulting body for the president (Liu, 2017).

Regarding public higher education institution's budget, China's Law on Higher Education specifies that the budget of public institution includes block grant budget and non-state purse. Public universities are allowed to raise funds through various channels, through running enterprise universities, renting out university's lands with the purpose of enhancing the services for students... besides the State's allowance. The Temporary Regulation on Managing the State's properties for higher education institution affiliated with the Ministry of Education (the Ministry of Education collaborate with Ministry of Finance, 2013) indicates that private enterprises are not allowed to invest in public universities. 
Table 3: A comparison of university council among three public universities in China

\begin{tabular}{|c|c|c|c|}
\hline & $\begin{array}{c}\text { East China Normal } \\
\text { University }\end{array}$ & $\begin{array}{l}\text { Yunnan Normal } \\
\text { University }\end{array}$ & Fuzhou University \\
\hline $\begin{array}{l}\text { Governing } \\
\text { body }\end{array}$ & $\begin{array}{l}\text { The Party Secretary } \\
\text { heads the university } \\
\text { council }\end{array}$ & $\begin{array}{l}\text { The president is also } \\
\text { the chairperson of the } \\
\text { university council }\end{array}$ & $\begin{array}{l}\text { University council's } \\
\text { members are elected } \\
\text { (head of university } \\
\text { council could be the } \\
\text { president or the Party } \\
\text { Secretary) }\end{array}$ \\
\hline \multirow[t]{2}{*}{ Authorities } & $\begin{array}{l}\text { Supervising the } \\
\text { administrative units and } \\
\text { socio-political units }\end{array}$ & \multicolumn{2}{|c|}{$\begin{array}{l}\text { Supervising and counseling President's decisions } \\
\text { regarding the development of the institution. } \\
\text { Raising and supervising endowment funds }\end{array}$} \\
\hline & & $\begin{array}{l}\text { Participating in } \\
\text { making decision } \\
\text { process related to } \\
\text { institution's } \\
\text { development, training } \\
\text { faculty members }\end{array}$ & $\begin{array}{l}\text { Electing university } \\
\text { council' members. } \\
\text { Coordinating the } \\
\text { cooperation between the } \\
\text { boards and other } \\
\text { administrative units }\end{array}$ \\
\hline
\end{tabular}

Source: Mai Ngoc Anh et al., 2017

Regarding to higher education quality assurance, higher education law specifies that, 'education quality of higher education institutions should be subject to the supervision and evaluation by the departments of educational administration' (Article 44). It is therefore, governmental agencies have been in charge of most types of higher education evaluation, non-governmental agencies have little chances to take part in any official evaluation schemes (Liu, 2016). Under the instruction of HEEC, the Chinese higher education institutions have also made great efforts to develop their own internal quality assurance schemes. Institutional teaching evaluation centers have been established in most universities. The evaluation procedures were standardized, a stratified and categorized evaluation system has been set up: (i) the HEEC of the MOE is in charge of the implementation of evaluation on HEIs directly affiliated with Ministry of Education and other Ministry of the central government and newly-built HEIs since 2000; (ii) the evaluation on other HEIs at provincial and municipal level will be organized by quality assurance agencies in relative provinces. There are 5 steps in procedure of evaluation have been figured out such as: self-evaluation, the analysis report of basic educational status data, site-visits, review and approval of the evaluation conclusion and finally continuous quality improvement. Higher education institutions must execute reforms following the recommendations. They were required to present reforming projects to the $\mathrm{MOE}$ and to report the achievement after one year reforms. The MOE published the evaluation results - excellent, good, qualified or unqualified in mass media (HEEC, 2016). 
Thirdly, in 2002, the China's Law on Promotion of Non-public Schools was passed to enhance the development of non-public higher education institutions. All of private higher education institutions were non-profit-seeking schools at that time. They received government subsidies in the form of cheap land and tax benefits, but they found it more difficult to give their shareholders any form of financial return. The amendment to China's Law on Promotion of Non-public Schools passed in 2016 was the first time to allow private higher education institutions to seek for profit. The revised law indicates that both for-profit and non-profit institutions are coexisted in higher education market. For profit higher education institutions, the subsidies and other incentives from government would be reduced. In return, they will have autonomy to adjust tuition fees at their discretion, particularly "reasonable rate of return" policy has been removed to this kind of non-public higher education institutions seeking for profit. The advantages of profit higher education institutions would be the disadvantages of non-profit higher education and vice versa.

\section{Discussion and conclusion}

According to China's higher education law, Chinese people have the right to study at higher education level, Chinese government has tried its best to serve the citizen. The centrally prescribed higher education system had existed in China before 1978; since then, this university governance pattern has been replaced by the state supervising model with the Chinese characteristics. Policies on university governance at the system level therefore have been adjusted to meet the requirements of socio-economic development as well come towards common norms in this area.

In the surge of institutions taking back their autonomy in the age of international integration and the influence of the same phenomenon due to the need of cutting government spending from Western countries (Donina et al., 2015), Chinese government neither impose this financial burden on students and their families, nor totally cut down on annual expenditure of public budget for public universities (Serger, Benner and Liu, 2015). Instead, the State sets a ceiling tuition fee level that institution fees cannot rise above, thus creates a flexible mechanism for public universities to determines tuition fees themselves (Marcucci and Usher, 2012), the remaining gaps in the annual expenditure of the higher education institutions are provided by the government with clear intention of "training those talented to be builders of Socialism with Chinese characteristics". The number of personnel in book of public higher education institutions is determined by the State Council. However, the State encourages institutions not to use up all the quota and to reserve some percentage for 3 -year-contract faculty members who exceed the requirement in teaching and researching. The fact that public employees of institutions are still partially paid by the State ensure that "university is the government extended arm, and tool for the State to improve its socioeconomic status" (Christensen 2010). This is also the main point of the changing to improve staffing autonomy and financial autonomy of public higher education institutions in not only China, but French and even Germany, where students are not charged and teachers are still civil servant (Nokkala and Bacenvic, 2014, Pruvot and Estermann, 2017) with the exception of UK, and Ireland where there is no public university across the countries (Mora, 2001). 
The establishment of the Board of Governors in public university is the inevitable development of every country all over the globe, and instead, Board of Governors had already re-appeared in some public higher education institutions in China since 1988 when China implement the Decision of the National Education Commission on Implementation of the University Principles of Responsibility; almost 30 years has passed until the Ministry of Education progulate the Resolution no. 37 on the trial establishment of the Board of Governors in public universities. Commonly, the Board of Governors is a unit of the institution and the executive organ of the university, which handles day-to-day affairs - and has the authority to appoint the Principal (Estermann and Nokkala, 2009, 2011). However in China, the university's grass-roots committees take upon this responsibility. In some public universities with school boards in China, if the Secretary of the school's grass-roots committees is not the Chairperson of the university's Board of Governor, this unit would only had the advisory position and the power to raise and supervise endowment funds, or at most having vote in deciding direction to run the institution. By including the establishment of the Board of Governors in public institutions with Chairperson being the Secretary of the university's grass-rooted committes, the managing body of Chinese university reaches the international standard in higher education but still secure the leading position of the Party in public higher education institution.

The study outlines Chinese higher education policy system and points out the difference between Chinese higher education system and the world's higher education system. The study also shows the differences among school boards and the financial autonomy policy in higher education. Along with that, some recommendations for future Chinese educational development are also mentioned in the study.

\section{Acknowledgment}

This research is funded by the Ministry of Education and Training of Vietnam (MOET), under grant number KHGD/16-20. ĐT003

\section{References}

Beijing Municipal Commission (2017): Regulations on the Establishment of Non-public Higher Education Institutions of Beïing, http://www.bjedu.gov.cn/bsfw/xzbs/ssxljyxqjy/mbgdjyjgsldsp/ (Chinese)

Chen, D. Y. (2004). China's Mass Higher Education: Problem, Analysis and Solutions. Asia Pacific Education Review. 5(1), 23-33

Chen D Y (2004). China's Mass Higher Education: Problem, Analysis and Solutions. Asia Pacific Education Review. 5(1), 23-33.

Christensen T (2010). University governance reforms: potential problems of more autonomy? The International Journal of Higher Education Research, 62(4), 503-517|

Deng, X. (1993). Selected Workes of Deng Xiaoping, Vol. 3. Beijing: People's Publishing House

Deng, X. (1994). Selected Works of Deng Xiaoping, 2nd edition, Vol. 2. Beijing: People's Publishing House

Donina D, Meoli and Paleari S (2015). Higher Education Reform in Italy: Tightening Regulation Instead of Steering at a Distance. Higher Education Policy, 28 (2), 215-234 
Estermann T, Nokkala T (2009). University autonomy in Europe I. Retrieved from http://www.rkrs.si/gradiva/dokumenti/EUA_Autonomy_Report_Final.pdf

Estermann T, Nokkala T and Steinel M (2011). University autonomy in Europe II. Retrieved from http://www.eua.be/Libraries/publications/University_Autonomy_in_Europe_II_The_S corecard.pdf?sfvrsn $=2$

HEEC (2016). Annual quality report of undergraduate Education in China

Hong. M. (2018). Public university governance in China and Australia: a comparative study. High Educ (https://doi.org/10.1007/s10734-018-0234-5)

Huang F (2003). Policy and Practice of the Internationalization of Higher Education in China. Journal of Studies in International Education, 7(3), p 225-240

Jia Q and Ericson D (2017). Equity and access to higher education in China: Lessons from Hunan Province for University admissions policy. International Journal of Educational Development, 52, p 97-110

Li M and Yang, R (2014). Governance reforms in higher education: A study of China, International Institute for Educational Planning, UNESCO. Retrieved from http://unesdoc.unesco.org/images/0023/002318/231858e.pdf

Liu S (2016) Quality assurance and institutional transformation: the Chinese experience, Springer

Liu X (2017) The governance in the development of public universities in China. Journal of Higher Education Policy and Management, 39 (3), 266-281

Liu X (2017) The governance in the development of public universities in China Journal of Higher Education Policy and Management 39 (3), 266-281. https://doi.org/10.1080/ 1360080X.2017.1300122

Mai Ngọc Anh et al (2017). Laws and by law documents related to higher education of the People's Republic of China and recommendations for higher education law revision of Vietnam, Seminar of the Committee of Culture, Education, Youth and children of Vietnam Congress

Marcucci P and Usher A. (2012) Global changes in Tuition Fee Policies and Student Assistance. Higher Education Strategy Associates. Retrieved from http://higheredstrategy.com/wpcontent/uploads/2012/03/YIR2012.pdf, Mora J (2001). Governance and management in the new university. Tertiary education and management. 7(2), p 95-110

Ministry of Education and Ministry of Finance, China (2013). Temporary Regulation on Managing the State's properties for bigher education institution affiliated with the Ministry of Education http://www.moe.gov.cn/srcsite/A05/s7052/201306/t20130619_181256.html (chinese)

Mohrman K, Geng Y, and Wang Y (2011). Faculty Life in China. The NEA 2011 Almanac of Hhigher Education (83-99). Washington, DC: National Education Association. Retrived from www.nea.org/assets/docs/HE/H-Mohrman_28Feb11_p83-100.pdf

Mok Ka-Ho (1999). Education and the market place in Hong Kong and Mainland China. Higher Education, 37, 133-158

Mok K (2002). Policy of decentralization and changing governance of higher education in Post-Mao China. Public Adminnistration and Development 22, p 261-273

Morgan. W. J and Wu. B (2011). Higher Education Reform in China Beyond the expansion, Routledge

Mora, J. (2001). Governance and Management in the new University. Tertiary education and management. 7(2), 95-110

National Congress of the People's Republic of China (1998). Law on Higher Education

National Congress of the People's Republic of China (2002). Law on the Promotion of Non-public Schools 
Mai Ngoc Anh, Do Thi Hai Ha, Nguyen Dang Nui, Khieu Thi Nhan, Nguyen Dinh Hung, Vu Tri Tuan $\mid 83$

National Congress of the People's Republic of China (2015). The Amendment to China's Law on Higher Education

National Congress of the People's Republic of China (2016). The Amendment to China's Law on the Promotion of Non-public Schools

Reddy K.S, Xie. E, Tang. Q 2016. Higher education, high-impact research, and world university rankings: A case of India and comparison with China. Pacific Science Review B: Humanities and Social Sciences. 1 - 21; http://dx.doi.org/10.1016/j.psrb.2016.09.004

Serger S, Benner M and Liu L (2015). Chinese university governance: Tensions and reforms. Science and Public Policy, 1-16, doi:10.1093/scipol/scv010

Shanghai Municipal Commission (2017): Regulations on the Establishment of Non-public Higher Education Institutions of Shanghai http://www.shmec.gov.cn/web/wsbs/onlineservices/ xzsp.php?id=A1 (chinese)

Su D, Zhou D, Liu C and Kong L (2015). Government-driven university-industry linkages in an emerging country: the case of China. Journal of Science \& Technology Policy management, 6(3), 263-282

Thorens (2006). Liberties, Freedom and Autonomy: A Few Reflections on Academia's Estate. Higher Education Policy, 19(1), 87-110

Vught F (1989). Governmental Strategies and Innovation in Higher Edu- cation. London: Jessica Kingsley

Wang L (2010). Higher education governance and university autonomy in China. Globalization, Societies and Education, 8(4), 477-495

Wang Q H, Wang H and Liu N C (2011) Building World-Class Universities in China: Shanghai Jiao Tong University. In Altbach P G and Salmi J (2011). The Road to Academic Excellence: The Making of World-Class Research Universities. World Bank. https://doi.org/10.1596/978-0-8213-8805-1

Xiulan Z (2011). China's Education Development and Policy, 1978-2008. Leiden, The Netherlands

Zha, Q. (2009) Diversification or homogenization: How government and markets have combined to (re)shape Chinese higher education in its recent massification process. Higher education, 58(1), 41-58

Zhu, H. and Lou, S. (2011). Development and Reform of Higher Education in China; Chandos Publishing; eBook ISBN: 9781780633596 